\title{
COVID-19 Outbreaks at Correctional Facilities Demand a Health Equity Approach to Criminal Justice Reform
}

\author{
Daniel Alohan • Michele Calvo (1)
}

Published online: 3 June 2020

(C) The New York Academy of Medicine 2020

Public health crises often bring to the forefront longstanding injustices, and the COVID-19 pandemic is no exception. We are seeing evidence of disparate impacts for people that have long faced barriers to health [1-5]. Incarcerated individuals are one such group, leading criminal justice reform advocates and public health experts to sound the alarm for reforms that many have been calling for to advance racial justice and health equity for decades. While we are not out of the woods yet, we ought to press for a long-term, bold transformation of our criminal-legal system that prioritizes community health and equity.

In March 2020, warning of an impending humanitarian crisis in jails and prisons caused by COVID-19, former New York City (NYC) Health Commissioner Dr. Mary Bassett and colleagues implored New York Governor Cuomo to implement swift and aggressive policy changes [6] to protect the health and lives of hundreds to thousands of people incarcerated. Michelle Bachelet, UN High Commissioner for Human Rights, framed the issue as a human rights injustice [7]. Some municipalities and states across the USA have

Daniel Alohan and Michele Calvo contributed equally to this work.

D. Alohan

Department of Sociomedical Sciences, Columbia University

Mailman School of Public Health, New York, NY, USA

e-mail: daniel.alohan@ columbia.edu

D. Alohan · M. Calvo $(\bowtie)$

New York Academy of Medicine, New York, NY, USA

e-mail: mcalvo@nyam.org responded with unprecedented reductions in jail and prison populations $[8,9]$; yet, advocates insist that more can be done [10].

At the New York Academy of Medicine, we have been promoting and researching public health approaches over punitive, criminal justice interventions for many decades, particularly around drug policy. With attention to the synergistic nature of structural racism, poverty, environmental exposures, ageism, and other social and structural factors that affect health, we believe that a health equity approach will help address inequities in the criminal justice system.

\section{The Legacy of Mass Incarceration During a Global Health Pandemic, Past and Present}

We must begin with a critical examination of the criminal justice system's history and its disparate impact on specific communities. Decades of institutional racism and discriminatory policies and practices have laid the foundation of the current system [11]. Broken windows policing and the 1973 Rockefeller Drug Laws, for example, heavily targeted Black and brown communities in their application [12]. It is well-documented that incarceration negatively affects the health of individuals, families, and communities [13, 14]. These harms threaten health equity, as the criminal-legal system disproportionately affects communities of color $[15,16]$.

COVID-19 has been compared with the highly fatal 1918 influenza pandemic, which was responsible for about 50 million casualties globally [17]. Maruschak 
et al. suggest that incarcerated individuals are particularly vulnerable during an influenza pandemic [18]. It is believed that the 1918 flu pandemic reached epic proportions, especially in places like California and Boston, because correctional health facilities were incredibly strained for vital resources and implemented illinformed policies [19, 20].

Similar inequities associated with the 1918 pandemic persist today, creating significant health disparities between African Americans and other racial/ethnic groups [21]. For example, during the pandemic, African Americans received subpar medical treatment in segregated healthcare facilities [22] and were subjected to substandard housing conditions [23]. Despite improved social conditions for African Americans since 1918 [24, 25], many have drawn parallels amid the COVID-19 pandemic [26-28]. For instance, in Nashville and Memphis, there are reports of disparate access to testing sites between White and Black neighborhoods, highlighting the inequitable distribution of resources [29].

\section{Detention Centers as Hotbeds for Disease Transmission}

Jails and prisons were not designed to brave a public health crisis like this. In fact, several characteristics of these facilities make them ideal places for the transmission of infectious diseases [30]:

1. Overcrowding and high levels of human contact

2. Unsanitary conditions and inadequate access to basic cleaning supplies

3. Severely limited capacity for healthcare services

Perhaps the most distinctive feature of detention settings is the restriction on personal freedoms that allow people in other settings to practice seemingly basic public health recommendations [31]. This may be best exemplified by the fact that in some facilities, hand sanitizer is considered contraband [32].

Furthermore, jails and prisons are not enclosed systems: the churning of people in and out of these facilities may increase community spread [33]. On any given week, approximately 200,000 people cycle in and out of jails [34], including jail staff and those detained [35].

Finally, incarcerated older adults and individuals with chronic conditions, including asthma and diabetes, are at an increased risk for COVID-19 [36]. Nearly half of incarcerated individuals have at least one chronic illness [37], and older incarcerated populations in particular are more likely to suffer from these conditions than the general population [38]. This burden of COVID-19 risk factors compounds the infrastructure challenges that jails and prisons face in implementing containment strategies.

\section{Unintended Consequences of COVID-19 Policy Changes}

As jurisdictions recognize the urgency of the situation through decarceration efforts, a number of new policies have emerged that may counteract this progress and exacerbate racial/ethnic inequities [39].

Increased police surveillance and enforcement of physical distancing laws may counterproductively increase the population of local jails and intensify jailbased COVID-19 outbreaks [40-42]. Exacerbating the issue in New York, the state recently rolled back elements of its sweeping bail reform policy aimed at reducing the jail population, most notably by expanding the list of bail-eligible offenses. As a result of these rollbacks [43, 44], a significant number of people may become detained during this pandemic [45]. Proponents of bail reform across the country, however, are unwavering in their plea for a moratorium on the prosecution of low-level and bail-eligible crimes [46].

\section{NYC Rikers Island Crisis as a Case Study for Criminal Justice Reform and Health Equity}

The number of identified COVID-19 cases among incarcerated individuals is rising at a staggering rate [47, 48]. Individuals detained at NYC's Rikers Island have an estimated crude infection rate over seven times that of the rest of the city [49]. Tragically, as of May 12, 2020, 352 people currently incarcerated in NYC jails are infected with COVID-19, and three people have died while in custody. An additional 192 health professional staff and 1387 correctional staff across NYC jails have tested positive for COVID-19 [50].

Various strategies are being employed to curb the spread of the virus among NYC high risk jail populations. Since March 16, the NYC jail population has been reduced by approximately $30 \%$ [51]. Those in need of 
emergency housing are released to hotels with onsite services to mitigate the impact on other congregate settings.

Despite these dramatic reductions, NYC continues to rely on the criminal justice system to enforce physical distancing and prosecute drug-related crimes, with reports suggesting racial/ethnic inequities in enforcement $[52,53]$. In fact, newly released New York Police Department data indicates that over $80 \%$ of individuals who were summoned for social distancing violations were Black or Hispanic [54]. Criminal justice reform advocates press on calling for further releases of incarcerated individuals, increased funding for reentry services, and an end to relying on the criminal justice system to address public health issues $[55,56]$.

\section{Health Equity During and After COVID-19}

Now, more than ever, our carceral system needs broad reforms rooted in health equity to stem the spread of COVID-19 and the disparities in morbidity and mortality. If carefully designed, reforms have the potential to make a long-lasting impact on the broader health and safety of communities. We suggest a four-pronged approach to integrating health equity into criminal justice reform:

1. We must address the underlying reasons why people are punished by the system, including poverty, substance use and mental illness, a lack of educational and economic opportunities, and systemic racism. Recognizing the importance of redirecting government resources to address these issues, the New York City Council has proposed to close Rikers Island by 2026 and invest millions of dollars into communities disproportionately impacted by mass incarceration through reentry, health, and preventive programs [57].

2. Policies and practices grounded in health, science, and compassion should be prioritized to reduce unnecessary community interactions with the criminal justice system. The First Step Act [58], enacted in December 2018, is a step in this direction by, for instance, relaxing mandatory minimums for certain drug offenses. Advocates have called for the elimination of criminal penalties associated with drugrelated crimes [59] and a reorientation to a health and harm reduction-oriented approach, inspired by the infamous Portugal model.

3. During incarceration and upon release, correctional supportive services must prepare individuals for successful reentry, such as access to medical treatment services and practical educational programs. Providing education in correctional settings is associated with positive outcomes [60]. Yet, nearly three in five people detained in prisons do not receive an education program while incarcerated [61]. The Bard Prison Initiative, for instance, offers incarcerated individuals an opportunity to earn associate of arts and bachelor of arts degrees [62].

Continuity of care following release can also be addressed for many individuals incarcerated by leveraging the Medicaid Waiver system to expand coverage and services to individuals leaving jails and prisons. This can be an especially powerful tool for connecting individuals with substance use disorders to evidence-based treatments upon release, a population that is at significant risk for drug-related deaths [63].

4. Lastly, local wisdom must be an integral component of the decision-making process, especially membership organizations. The Institute for Law and Justice's guidance on community engagement echoes this sentiment, emphasizing the need to identify community strengths in forming neighborhoodpolice collaboration efforts [64].

Criminal justice reform is intricately tied to public health and health equity. We can no longer afford to ignore social and structural inequities that affect justiceinvolved individuals - today and after shelter-in-place orders end.

Acknowledgements This work was partially supported by a grant from the Drug Policy Alliance. The authors thank Sarita Daftary and \#buildCOMMUNITIES partners for their direction and inspiration for this commentary.

\section{References}

1. Pereira S. Coronavirus outbreak inflicting "severe" economic damage on immigrant workers as NYC scrambles to slow spread - Gothamist. Gothamist. https://gothamist. com/news/coronavirus-immigrants-nyc-economy-covid-19. Published March 17, 2020. Accessed May 1, 2020. 
2. Hoffman J. With meetings banned, millions struggle to stay sober on their own - The New York Times. New York Times. https://www.nytimes.com/2020/03/26/health/coronavirusalcoholics-drugs-online.html. Published March 26, 2020. Accessed May 1, 2020.

3. Wong A. Does the coronavirus pandemic make someone who is disabled like me expendable? - Vox. Vox. https://www.vox.com/first-person/2020/4/4/21204261 /coronavirus-covid-19-disabled-people-disabilities-triage. Published April 4, 2020. Accessed May 1, 2020.

4. Farmer B (Nashville PR. Long-Standing Racial And Income Disparities Seen Creeping Into COVID-19 Care | Kaiser Health News. Kaiser Health News. https://khn. org/news/covid-19-treatment-racial-income-healthdisparities/. Published April 6, 2020. Accessed May 1, 2020.

5. Stewart N. 'It's a time bomb': 23 die as virus hits packed homeless shelters - The New York Times. New York Times. https://www.nytimes.com/2020/04/13/nyregion/new-yorkcoronavirus-homeless.html. Published April 12, 2020. Accessed May 1, 2020.

6. Bassett M, Gonzalez E, Walker D. Opinion | Andrew Cuomo, Stop a coronavirus disaster: release people from prison - The New York Times. New York Times. https://www.nytimes.com/2020/03/30/opinion/nyc-prisonrelease-covid.html. Published March 30, 2020. Accessed May 1, 2020.

7. UN rights chief urges quick action by governments to prevent devastating impact of COVID-19 in places of detention | UN News. United Nations. https://news.un. org/en/story/2020/03/1060252. Published March 25, 2020. Accessed May 1, 2020.

8. O'Sullivan J. Washington state to free as many as 950 prisoners to limit coronavirus outbreaks | The Seattle Times. The Seattle Times. https://www.seattletimes. com/seattle-news/politics/washington-state-to-move-someprisoners-back-to-county-jails-to-help-prevent-coronavirusoutbreak/. Published April 13, 2020. Accessed May 1, 2020.

9. Rosenberg R. More than 1,500 NYC inmates have been released amid coronavirus crisis. New York Post. https://nypost.com/2020/04/10/more-than-1500-nycinmates-have-been-released-amid-coronavirus-crisis/. Published April 20, 2020. Accessed May 1, 2020.

10. Walker H. The coronavirus outbreak in NY prisons: advocates call on Cuomo for clemency - VICE.https://www.vice. com/en_us/article/7kzya9/new-york-prisons-coronavirusoutbreak-cuomo-clemency. Published April 13, 2020. Accessed May 1, 2020.

11. Bowleg L. Reframing mass incarceration as a socialstructural driver of health inequity. Am J Public Health. 2020;110(S1):S11-2. https://doi.org/10.2105 /AJPH.2019.305464.

12. Hinton E, Brief VE. An Unjust Burden: The Disparate Treatment of Black Americans in the Criminal Justice S y s t e m .; 2018 . h t t ps:// w w w. vera. org/downloads/publications/for-the-record-unjust-burdenracial-disparities.pdf. Accessed May 1, 2020.

13. Brinkley-Rubinstein L. Incarceration as a catalyst for worsening health. Heal Justice. 2013;1(1):3. https://doi. org/10.1186/2194-7899-1-3.
14. Gifford EJ. How incarceration affects the health of communities and families. N C Med J. 2019;80(6):372-5. https://doi.org/10.18043/ncm.80.6.372.

15. Acker J, Baveman P, Arkin E, Leviton L, Parsons J, Hobor G. Incarceration threatens health equity in America. 2019. https://www.rwjf.org/en/library/research/2019/01/massincarceration-threatens-health-equity-in-america.html. Accessed 1 May 2020.

16. The Sentencing Project. Report of The sentencing project to the United Nations special rapporteur on contemporary forms of racism, racial discrimination, xenophobia, and related intolerance. 2018. https://www.sentencingproject. org/publications/un-report-on-racial-disparities/. Accessed 1 May 2020.

17. Boyce M, Katz R. The 1918 Influenza pandemic and COVID-19. American Experience, PBS https://wwwpbsorg/wgbh/americanexperience/ features/1918-influenza-pandemic-and-covid-19/ Published March 18, 2020. Accessed May 1, 2020.

18. Maruschak LM, Sabol WJ, Potter RH, Reid LC, Cramer EW. Pandemic influenza and jail facilities and populations. Am J Public Health. 2009;99(S2):S339-44. https://doi. org/10.2105/AJPH.2009.175174.

19. Chaddock D. 1918 flu pandemic puts prison medical staff to test. October 2018. https://www.cdcr.ca. gov/insidecder/2018/10/18/1918-flu-pandemic-puts-prisonmedical-staff-to-test/. Accessed May 1, 2020.

20. Green A. Just like the coronavirus, the 1918 flu pandemic ravaged group living facilities - The Boston Globe. The Boston Globe. https:/www.bostonglobe.com/2020/04/10 /opinion/just-like-coronavirus-1918-flu-pandemic-ravagedgroup-living-facilities/. Published April 9, 2020. Accessed May 1, 2020.

21. McDonald S. In 1918 and 2020, race colors America's response to epidemics. The Undefeated. 2020. https://theundefeated.com/features/in-1918-and-2020-racecolors-americas-response-to-epidemics/. Accessed May 1, 2020.

22. Gamble VN. "There wasn't a lot of comforts in those days:" African Americans, Public Health, and the 1918 Influenza Epidemic. Public Health Rep. 2010;125(3_suppl):113-22. https://doi.org/10.1177/00333549101250S314.

23. Økland H, Mamelund S-E. Race and 1918 influenza pandemic in the United States: a review of the literature. Int $J$ Environ Res Public Health. 2019;16(14):2487. https://doi. org/10.3390/ijerph16142487.

24. Berube A. Black household income is rising across the United States. Brookings Inst Blog, Ave. 2019. https://www.brookings.edu/blog/the-avenue/2019/10/03 /black-household-income-is-rising-across-the-united-states/. Accessed May 1, 2020.

25. Jones J, Schmitt J, Wilson V. 50 Years after the Kerner Commission. 2018. https://www.epi.org/publication/50years-after-the-kerner-commission/. Accessed May 1, 2020.

26. Blackstock U. What the COVID-19 pandemic means for Black Americans - scientific American blog network. Sci Am. 2020. https://blogs.scientificamerican. com/voices/what-the-covid-19-pandemic-means-for-blackamericans/. Accessed May 1, 2020.

27. Maybank A. The pandemic's missing data. The New York Times. https://www.nytimes.com/2020/04/07 
/opinion/coronavirus-blacks.html. Published April 7, 2020. Accessed May 1, 2020.

28. Cineas F. Coronavirus is disproportionately taking black lives - Vox. Vox. 2020. https://www.vox. com/identities/2020/4/7/21211849/coronavirus-blackamericans. Accessed May 1, 2020.

29. Farmer B. Racial bias showing up in coronavirus testing and treatment. Health News, NPR. https://www.npr. org/sections/health-shots/2020/04/02/825730141/thecoronavirus-doesnt-discriminate-but-u-s-health-careshowing-familiar-biases. Published April 2, 2020. Accessed May 1, 2020.

30. Dolan K, Wirtz AL, Moazen B, Ndeffo-mbah M, Galvani A, Kinner SA, et al. Global burden of HIV, viral hepatitis, and tuberculosis in prisoners and detainees. Lancet. 2016;388(10049):1089-102. https://doi.org/10.1016 /S0140-6736(16)30466-4.

31. How to Protect Yourself \& Others | CDC. Centers for Disease Control and Prevention. https://www.cdc. gov/coronavirus/2019-ncov/prevent-gettingsick/prevention.html. Published 2020. Accessed May 1, 2020.

32. Farzam AN. New York Gov. Andrew M. Cuomo criticized for using prison labor to make hand sanitizer as coronavirus spreads - The Washington Post. The Washington Post. https://www.washingtonpost.com/nation/2020/03/10/handsanitizer-prison-labor/. Published March 10, 2020. Accessed May 1, 2020.

33. Klonsky A. Opinion $\mid$ An epicenter of the pandemic will be jails and prisons, if inaction continues - The New York Times. The New York Times. https://www.nytimes. com/2020/03/16/opinion/coronavirus-in-jails.html. Published March 16, 2020. Accessed May 1, 2020.

34. Flagg A, Neff J. Why jails are so important in the fight against coronavirus | The Marshall Project. The Marshall Project. https://www.themarshallproject.org/2020/03/31 /why-jails-are-so-important-in-the-fight-againstcoronavirus. Published March 31, 2020. Accessed May 1, 2020 .

35. Kinner SA, Young JT, Snow K, Southalan L, Lopez-Acuña $\mathrm{D}$, Ferreira-Borges C, et al. Prisons and custodial settings are part of a comprehensive response to COVID-19. Lancet Public Heal. 2020;5(4):e188-9. https://doi.org/10.1016 /S2468-2667(20)30058-X.

36. People Who Are at Higher Risk for Severe Illness. Centers for Disease Control and Prevention. https://www.cdc. gov/coronavirus/2019-ncov/need-extra-precautions/peopleat-higher-risk.html. Published 2020. Accessed May 1, 2020.

37. Maruschak LM, Berzofsky M, Unangst J. Medical problems of state and federal prisoners and jail inmates, 2011-12. 2015. https://www.bjs.gov/content/pub/pdf/mpsfpji1112. pdf. Accessed May 1, 2020.

38. Udo T. Chronic medical conditions in U.S. adults with incarceration history. Health Psychol. 2019;38(3):217-25. https://doi.org/10.1037/hea0000720.

39. Kim C. Why some states are releasing prisoners during the coronavirus pandemic - Vox. Vox. April 2020. https://www. vox.com/2020/4/3/21200832/jail-prison-early-releasecoronavirus-covid-19-incarcerated. Accessed May 1, 2020.

40. Guzman J. New York doubles max fine for breaking social distancing orders | TheHill. The Hill. https://thehill. com/changing-america/well-being/preventioncures/491418-new-york-doubles-max-fine-for-breakingsocial. Published April 6, 2020. Accessed May 1, 2020.

41. Raymond AK. Social distancing enforcement drones arrive in the U.S. New York Mag. April 2020. https://nymag. com/intelligencer/2020/04/social-distancing-enforcementdrones-arrive-in-the-u-s.html. Accessed May 1, 2020.

42. Orden E. Social distancing fines: How they are working and not working across America -. CNN Politics. https://www. cnn.com/2020/04/11/politics/behind-social-distancingfines/index.html. Published April 11, 2020. Accessed May 1 , 2020.

43. Coltin J. How New York changed its bail law . City and State New York. https://www.cityandstateny. com/articles/policy/criminal-justice/how-new-yorkchanged-its-bail-law.html. Published April 4, 2020. Accessed May 1, 2020.

44. Rahman I. New York, New York: Highlights of the 2019 Bail Reform Law.; 2019 . https://www.vera. org/downloads/publications/new-york-new-york-2019-bailreform-law-highlights.pdf. Accessed May 1, 2020.

45. Schuppe J. Jails are releasing inmates because of coronavirus. New York just took a step to lock more people up. $N B C$ News . https://www.nbcnews.com/news/us-news/jails-arereleasing-inmates-because-coronavirus-new-york-just-tookn1179041. Published April 8, 2020. Accessed May 1, 2020.

46. Prosecutors Responses to Covid-19| Brennan Center for Justice. 2020. https://www.brennancenter.org/ourwork/research-reports/prosecutors-responses-covid-19. Accessed May 1, 2020.

47. Cases in the U.S. CDC. https://www.cdc. gov/coronavirus/2019-ncov/cases-updates/cases-in-us. html\#cumulative. Accessed May 1, 2020.

48. Federal Defenders of New York-COVID-19 RESPONSE. Federal Defenders of NY. https://federaldefendersny.org/. Published March 2020. Accessed May 1, 2020.

49. COVID-19 infection tracking in NYC jails. The Legal Aid Society. https://legalaidnyc.org/covid-19-infection-trackingin-nyc-jails/. Published March 2020. Accessed May 1, 2020.

50. Board of Correction Daily Covid-19 Update Monday, May 25, 2020. New York City Board of Correction. https://www1.nyc.gov/assets/boc/downloads/pdf/ News/covid-19/Public_Reports/Board\%20of\%20 Correction\%20Daily\%20Public\%20Report_5_25_2020. pdf. Published May 25, 2020. Accessed May 26, $20 \overline{2} 0$.

51. New York City Jail Population Reduction in the Time of COVID-19 - Weekly Update.; 2020. https://criminaljustice. cityofnewyork.us/wp-content/uploads/2020/05/COVIDfactsheet_APRIL-30-2020.pdf. Accessed May 1, 2020.

52. Offenhartz J, Nessen S. MTA's first overnight subway shutdown begins with confused riders, displaced homeless. Gothamist. https://gothamist.com/news/mtas-firstovernight-subway-shutdown-begins-confused-ridersdisplaced-homeless. Published May 6, 2020. Accessed 13 May 2020.

53. Poggio M, Parascandola R, Mcshane L. SEE IT: NYPD roughly arrests men defying social distancing in Brooklyn. New York Daily News. https://www.nydailynews.com/newyork/nyc-crime/ny-brooklyn-social-distancing-arrestsvideo-20200505-tiud5nzjzrgffp3is4blfv4fr4-story.html. Published May 5, 2020. Accessed 13 May 2020. 
54. Chapman B, Honan K. NYPD data shows racial disparities in social-distancing enforcement - WSJ. Wall Street Journal. https:/www.wsj.com/articles/nypd-data-shows-racialdisparities-in-social-distancing-enforcement-11588964081. Published May 8, 2020. Accessed May 13, 2020.

55. Westervelt E. Advocates: inmates released early due to pandemic need help to safely shelter. National Public Radio. https://www.npr.org/2020/04/09/830394249 /advocates-inmates-released-early-due-to-pandemic-needhelp-to-safely-shelter. Published April 9, 2020. Accessed May 1, 2020.

56. ACLU Letter to state and local officials on COVID-19 and the criminal justice system $\mid$ American Civil Liberties Union. The American Civil Liberties Union. https://www.aclu. org/letter/aclu-letter-state-and-local-officials-covid-19-andcriminal-justice-system. Published March 16, 2020. Accessed May 1, 2020.

57. City invests $\$ 391$ million in communities and comprehensive reforms to the criminal justice system - Press. New York City Counc. October 2019. https://council.nyc. gov/press/2019/10/17/1817/. Accessed May 1, 2020.

58. Collins D. Text - H.R.5682 - 115th Congress (2017-2018): FIRST STEP act. Congr Bill 2018. https://www.congress. gov/bill/115th-congress/house-bill/5682/text. Accessed May 1, 2020.

59. It's time for the U.S. to decriminalize drug use and possession. 2017 . https://www.drugpolicy. org/sites/default/files/documents/Drug_Policy_Alliance_
Time_to_Decriminalize_Report_July_2017.pdf. Accessed May $\overline{1}, \overline{20} 20$.

60. Davis L, Bozick R, Steele J, Saunders J, Miles J. Evaluating the effectiveness of correctional education: a meta-analysis of programs that provide education to incarcerated adults. RAND Corporation. 2013; https://doi.org/10.7249/RR266.

61. Oakford P, Brumfield C, Goldvale C, Tatum L, Dizerega M, Patrick F. Investing in futures: economic and fiscal benefits of postsecondary education in prison January 2019. 2019. https://www.vera.org/downloads/publications/investing-infutures.pdf. Accessed May 1, 2020.

62. By The Numbers - Bard Prison Initiative. https://bpi.bard. edu/by-the-numbers/. Accessed May 1, 2020.

63. Merrall ELC, Kariminia A, Binswanger IA, Hobbs MS, Farrell M, Marsden J, et al. Meta-analysis of drug-related deaths soon after release from prison. Addiction. 2010;105: 1545-54. https://doi.org/10.1111/j.1360-0443.2010.02990. $\mathrm{x}$.

64. Griffith B, Thiemann R, Mock L, et al. Engaging the Community in Project Safe Neighborhoods. 2005. http://www.ilj.org/publications/docs/Engaging Community_Project_Safe_Neighborhoods.pdf. Accessed May $1,2020$.

Publisher's Note Springer Nature remains neutral with regard to jurisdictional claims in published maps and institutional affiliations. 